\title{
Virtual 3D Urban Landscape Design Taman Kota Berbasis Teknologi Komputer Grafis
}

\author{
Edy Jogatama Purhita ${ }^{1}$, AnthoniusTyas Adi Pratama ${ }^{2}$, Erwan Nur Hidayat ${ }^{3}$ \\ 1,2, Universitas Sains Teknologi dan Komputer, e-mail: edyjogatama@stekom.ac.id \\ ${ }^{2}$ STIE Studi Ekonomi Modern, e-mail: erwannurhidayat@stekom.ac.id
}

\section{ARTICLE INFO}

Article history:

Received 2 Oktober 2021

Received in revised form 9 Oktober 2021

Accepted 16 November 2021

Available online 1 Desember 2021

\section{ABSTRACT}

Urban landscape design is an approach in designing cities that has a positive impact on city residents by providing a livable environment. Urban landscapes come in various forms, one of which is city parks. A city park is one of the facilities provided by a city and its residents can carry out several activities in it. A city park also serves as a city landmark. The city of Salatiga has several parks with recreational functions but not many city parks are available to function as public spaces. One of them is a park located in Tingkir District, Salatiga City, namely Tingkir Park. The purpose of this study was to apply 3D computer technology in the redesign of Tingkir park with the concept of Urban landscape design. A city park that is functional, aesthetically pleasing, can be a better public space and can become a landmark in the area. The method of developing a Virtual 3D City Park Design product uses 5 steps ADDIE (Analysis, Design, Development, Implement and Evaluation). In academic interest, this research results in the experimentation of computer graphics technology in the development of urban park design.

Keywords: Virtual 3D, graphic computer, landscape Design.

\section{PENDAHULUAN}

Taman kota merupakan fasilitas yang disediakan oleh kota agar penduduknya bisa melakukan beberapa kegiatan di dalamnya. Desain lansekap perkotaan (urban landscape design) merupan desain kawasan perkotaan yang mampu memberikan lingkungan yang layak huni dan memberi dampak positif bagi penghuni kota. Salatiga merupakan salah satu kota di Jawa Tengah yang menyediakan fasilitas perkotaan berupa taman kota bagi warganya. Diantara beberapa taman kota yang ada di kota Salatiga adalah Taman Tingkir, yang dibuka mulai tahun 2016. Taman tersebut berlokasi di Jl. Marditomo, Kelurahan Sidorejo Kidul, Kecamatan Tingkir, Kota Salatiga. Dengan luas lahan kurang lebih $11.000 \mathrm{~m} 2$ berada tidak jauh dari lingkungan pemukiman penduduk kota yang memiliki beragam aktifitas [1]. Taman tersebut selain memberikan keindahan kota juga merupakan fasilitas rekreatif, juga diharapkan menjadi ruang publik (public space) bagi warga kota. Dalam pengertian ruang publik dimana seluruh elemen masyarakat memiliki akses untuk menggunakan fasilitas yang disediakan taman tersebut dengan beragam kepentingannya. [2] Karakteristik publik space adalah terbuka dan mudah diakses untuk melakukan 
kegiatan secara berkelompok, tidak selalu terdapat unsur tanaman (vegetasi). Bentuknya bisa berupa plaza, arena bermain, panggung pertunjukan dan banyak bentuk lainnya yang bisa menjadi ruang kegiatan bersama.

Beberapa problematika yang mengemuka diantaranya adalah taman Tingkir kota Salatiga digunakan untuk berbagai macam kegiatan yang dilakukan oleh pengunjung taman, mulai dari balita sampai lanjut usia sangat beragam seperti berolahraga, bermain, menunggu, hingga jual beli. Namun pengelolaan dan pemeliharaan Taman Tingkir kurang baik, terlihat dari beberapa fasilitas yang dimiliki oleh Taman Tingkir tidak difungsikan sebagaimana mestinya. Contoh beberapa fasilitas yang tidak terpakai atau tidak berfungsi sebagai mana mestinya antara lain adalah kolam, alat fitness dan kandang burung. Dari segi akses di taman, area pejalan kaki atau trotoar dibagian luar taman digunakan untuk para pedagang menjajakan dagangannya dan persewaan mobil mainan anak anak, sehingga mengurangi kenyamanan pejalan kaki saat melewati area trotoar. Perlu akses penyandang disabilitas dalam menggunakan fasilitas taman. Dalam segi kebersihan, pengelolaan sampah kurang optimal, perlu fasilitas tong sampah yang sesuai jenis sampah dan penempatannya mudah diakses. Pada saat hujan, di area bermain anak menjadi becek karena alas taman bermain berupa tanah dan pasir. Aktifitas pada Taman Tingkir banyak terlihat pada saat pagi hingga sore, dan taman ini ramai dikunjungi pada saat weekend dan hari libur nasional. Pada saat malam hari, sangat jarang terlihat adanya aktifitas pada taman ini, karena kondisi pencahayaan dalam taman yang kurang memadai.

Tujuan penelitian ini adalah untuk menerapkan teknologi komputer rancang bangun 3D dalam mendesain ulang (redesign) taman Tingkir dengan konsep Urban landscape design, dari segi fungsional dan estetika yang nantinya juga bisa menjadi tengara atau landmark di Kota Salatiga, sehingga fungsi Taman Tingkir sebagai public space dapat terpenuhi. Peneliti membatasi masalah masalahnya terkait pembuatan desain virtual 3D fasilitas Taman Tingkir Kota Salatiga, memuat produk desain berupa gambar dan video fasilitas Taman Tingkir Kota Salatiga, Implementasi desain ulang Taman Tingkir sesuai kebijakan Pemkot Salatiga. Penelitian ini diharapkan bisa menjadi masukan untuk Pemerintah kota Salatiga dalam pengembangan taman Tingkir kedepannya.

\section{TINJAUAN PUSTAKA}

Dalam penelitian terkait, Irfan Adi Permana dan Indung Sitti Fatimah (2017) melakukan penelitian berjudul "Redesign Taman Kota Kabupaten Bogor dengan Pendekatan Urban Landscape Design". Penelitian tersebut menghasilkan desain taman kota dengan konsep Urban Landscape Design memanfaatkan sumberdaya yang ada pada masa kini dan membentuknya menjadi sebuah karya yang dapat dicintai oleh banyak orang, karena desain yang dihasilkan adalah berdasarkan kebutuhan sumberdaya manusia itu sendiri [3]. Yudhistira Adi Nugroho (2018), melakukan penelitian terkait Taman Tingkir kota Salatiga dengan fokus penelitannya pada Keamanan dan Kenyamanan Trotoar di Taman Tingkir Kota Salatiga. Dari segi fisik, trotoar pada Taman Tingkir sudah dalam kategori aman dan nyaman, akan tetapi PKL membuat trotoar pada Taman Tingkir menjadi kurang aman dan nyaman [4].

Peneliti memberikan "Perancangan Virtual 3D Urban Landscape Design Taman Kota berbasis Teknologi Komputer Grafis". Penelitian ini mengembangkan desain Taman Tingkir Kota Salatiga mengguna konsep Urban Landscape Design. Kata Urban berasal dari bahasa latin 'Urbs' yang artinya orang bebas dan beradab, tempat yang bermasyarakat, berbudaya, dan berpemerintah. Kata urban juga dikaitkan dengan gedung-gedung perkotaan yang menjulang tinggi, sehingga secara keseluruhan akan terlihat susunan garis-garis perspektif menghubungkan titik-titik obyek satu titik obyek lainnya [3]. Lansekap merupakan suatu sistem dalam kawasan yang menyeluruh yang di dalamnya terdapat hubungan antara komponen biotik dan abiotik, termasuk komponen pengaruh manusia. Urban Landscape Design secara garis besar yaitu memanfaatkan sumberdaya dan tata guna lahan sekitar yang ada, dan membentuknya atau ditrasnformasikan menjadi sebuah karya, taman atau bangunan yang dapat menunjang aktivitas kehidupan sehari-hari manusia dalam kehidupan sehari hari dan disukai banyak orang. Bentuk desain taman yang dihasilkan dapat menghadirkan suatu wilayah terpadu dengan pola pengembangan kota. Seiring waktu manusia perubahan maka Urban Design tidak pernah sama ssetiap masanya karena juga mengikuti perubahan [5] [6].

Taman Tingkir merupakan bagian dari Ruang Tebuka Hijau (RTH) Kota Salatiga. Pengertian ruang menurut Permendagri No.1, 2007 Tentang Penataan Ruang Terbuka Hijau Kawasan Perkotaan, adalah wadah meliputi darat, ruang laut, dan ruang udara, termasuk ruang di dalam bumi sebagaisatu kesatuan

Virtual 3D Urban Landscape Design Taman Kota Berbasis Teknologi Komputer Grafis 
wilayah, tempat manusia dan makhluk hidup lain hidup, melakukan kegiatan, dan memelihara kelangsungan hidupnya. RTH dalam konsep taman kota memiliki peran menyelaraskan pola kehidupan masyarakat perkotaan [7]. Taman kota sebagai RTH merupakan kawasan yang penggunaannya lebih bersifat terbuka, menjadi tempat tumbuhnya tanaman secara alamiah maupun sengaja ditanam oleh pemertintah kota, dan digunakan memfasilitasi kepentingan masyarakat umum.

Taman Tingkir merupakan taman kota yang menjadi Public Space dan Landmark Kota Salatiga. Public Space atau Ruang Publik merupakan ruang terbuka dengan akses yang gratis untuk masyarakat umum, yang digunakan untuk melakukan interaksi social. Fasilitas kota yang mampu menarik banyak pengunjung untuk melakukan berbagai kegiatan individual maupun kelompok, baik bersifat informal maupun formal, bisa untuk rekreasi serta mudah diakses oleh semua kalangan. Ruang publik yang berkualitas tinggi memiliki kriteria punya sistem akses dan pergerakan yang jelas dan mudah. Diantaranya adalah dengan menciptakan jalur akses yang jelas untuk menghubungkan satu sama lain dengan integrasi moda transportasi, serta penggunaan lahan dan keberadaan landmark sebagai orientasi [8]. Titik Orientasi Visual (Landmark) adalah hal yang menonjol, penunjuk kejadian peristiwa penting dan sesuatu yang mudah dilihat atau dikenal yang digunakan untuk pembentukan citra pada lingkup kota dalam lansekap tertentu. Keistimewaan dan keunikan citra tersebut akan menjadi pembeda dengan suatu hal lainnya sehingga memancing perhatian masyarakat luas [9] [10].

Rancangan Desain akan dibuat secara virtual 3D, realitas maya desain Taman Tingkir akan disajikan dengan menggunakan teknologi komputer grafis. Perangkat lunak SketchUp digunakan dalam rancang bangun tiga dimensi (3D). Software ini merupakan sebuah program grafis yang diproduksi oleh google. Program ini memberikan hasil utama yang berupa gambar sketsa grafik 3 dimensi. Dalam pra-desain, parangkat ini lebih mudah digunakan untuk membuat objek 3 dimensi dengan perbandingan pajang, lebar maupun tinggi dengan ukuran skalatif. Pengeditanya lebih mudah dibanding bila menggunakan perangkat lunak grafis lain serta dapat menghasilkan gambar yang cukup baik untuk keperluan presentasi, dan mampu membuat visualisasi gambar 3D [11].

Perangkat lunak Adobe Premiere Pro adalah bagian dari Adobe System merupakan program yang digunakan untuk menyunting video. Fasilitas software ini banyak dalam memberikan efek editing dan plugin yang bekerja secara cepat. Kompatibel dengan banyak format file audio maupun video. Software ini juga digunakan untuk melakukan rendering project video [12]. Perangkat lunak ini dalam penelitian digunakan untuk menyunting (memotong atau menggabungkan) hasil Export file yang berupa video dari aplikasi SketchUp.

Perangkat lunak Adobe Photoshop merupakan software yang digunakan untuk pengolahan citra, mengedit dan memanipulasi image gambar atau foto. Fasilitas yang disediakan sangat lengkap, yaitu berbagai macam tools untuk mengedit foto, fasilitas filter untuk memberikan berbagai efek pada image gambar atau foto, serta fasilitas untuk memanipulasi warna, dan lain-lain. Adobe Photoshop memberikan kemudahan dalam penyempurnaan sebuah gambar atau foto [13]. Pada penelitian ini, Adobe Photoshop digunakan untuk menyunting gambar hasil dari renderV-Ray. Penyuntingan yang dilakukan antara lain mengubah background dan mengatur tone warna.

Penerapan Teknologi Komputer Grafis dalam perancangan Virtual 3D taman tingkir dapat digambarkan dalam bagan berikut (Gambar 1).

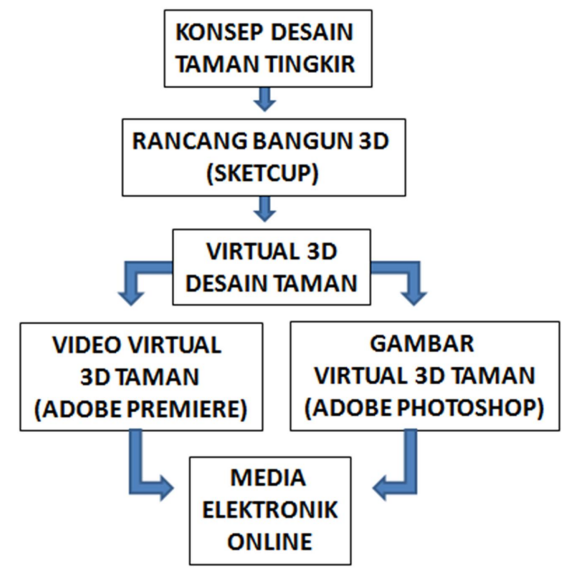

Gambar 1. Bagan Aplikasi Teknologi Komputer Grafis Perancangan Taman

JURNAL ILMIAH KOMPUTER GRAFIS Vol. 13, No. 1, Juli 2020: $1-8$




\section{METODOLOGI PENELITIAN}

Tahapan yang dilalui dalam penelitian, pembangunan konsep, atau penyelesaian kasus, dituliskan pada bagian metodologi. Dari permasalahan yang dirumuskan, maka dilakukan tahap perencanaan desain Taman Tingkir. Pada tahap ini, dilakukan Studi Literatur tentang teori dan penelitian terkait perancangan taman maupun pemanfaatan teknologi dalam proses desain. Dilakukan juga studi pendahuluan dengan Observasi langsung pada objek penelitian, lalu Interview ke beberapa pihak, contohnya adalah warga sekitar dan Pemkot Salatiga selaku pengelola Taman Tingkir. Instrumen penelitian berupa kuesioner dibagikan kepada para pengunjung Taman Tingkir. Metode pengembangan produk Virtual 3D Desain Taman Kota menggunakan 5 langkah ADDIE (Analysis, Design, Development, Implementand Evaluation) (Gambar 3) [14], meliputi :

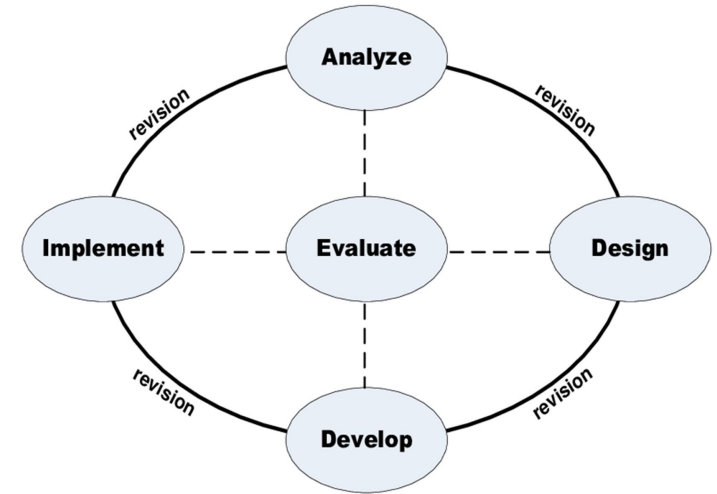

Gam bar 3. Metode Pengembangan Produk Desain ADDIE

a) Fase Analisis (Analyze) :

Fase Analisis adalah dasar untuk semua fase Pengembangan Desain Taman Kota. Selama fase ini, peneliti mendefinisikan masalah, mengidentifikasi sumber masalah, dan menentukan solusi yang mungkin. Fase tersebut dapat mencakup teknik penelitian khusus seperti analisis kebutuhan, analisis tujuan, dan analisis komparasi taman kota lainnya. Keluaran dari fase ini adalah Naskah Akademik Study Pendahuluan Taman Tingkir Kota Salatiga. Keluaran ini akan menjadi masukan untuk tahap Desain.

b) Tahap Desain (Design) :

Tahap Desain melibatkan penggunaan keluaran dari tahap Analisis untuk merencanakan strategi dalam mengembangkan Desain Taman. Selama fase ini, peneliti menguraikan bagaimana mencapai tujuan perancangan Taman Kota Tingkir yang ditentukan selama fase Analisis dan memperluas landasan konseptual/teoritiknya untuk implementasi konsep desain taman kota. Beberapa elemen dari Tahap Desain termasuk membuat sketsa denah taman dan zonasinya, referensi gaya visual desain, identifikasi komponenkomponen taman kota secara virtual 3D. Keluaran fase ini adalan Naskah kreatif Konsep Desain Taman Kota (Creative Brief) termasuk sketsa2 desain. Output dari tahap Design akan menjadi masukan untuk tahap Development.

\section{c) Fase Pengembangan (Develop) :}

Tujuan dari tahap ini adalah untuk menghasilkan prototype virtual 3D Desain Taman Tingkir. Selama tahap ini peneliti membangun dan mengembangkan rancang bangun 3D komponen dengan bantuan perangkat lunak sketchup. Output sketcup dan rendering Vray bisa berupa file Gambar yang akan diolah dengan software photoshop. Rendering animasi 3D dari sketcup yang berupa video akan diolah menggunakan Adobe Premiere untuk bisa disajikan dalam beragam media presentasi, publikasi dan dokumentasi. Ini akan melibatkan perangkat keras komputer grafis dan perangkat lunak pendukung lainnya. d) Tahap Implementasi (Implement) :

Fase implementasi mengacu pada penyajian Desain Taman Tingkir kota Salatiga kepada stakeholder terkait, baik untuk kepentingan informasi, presentasi maupun publikasi Desain. Fase ini harus mempromosikan rancangan Desain Taman Tingkir, mendukung informasi, referensi data dan analysa pengembangan Taman Tingkir bagi pengelola/ pemkot salatiga. Juga menjadi wahana informasi serta edukasi bagi pengguna Taman tingkir. Prototype Desain Taman Tingkir akan dilakukan pengujian kelayakan desain taman kota, dilakukan oleh pengelola dan membagikan kuesioner ke pengunjung Taman

Virtual 3D Urban Landscape Design Taman Kota Berbasis Teknologi Komputer Grafis 
Tingkir. Hal ini akan menjadi bahan penyempurnaan Desain sebelum diimplementasikan sebagai produk final desain.

e) Tahap Evaluasi (Evaluate) :

Tahap ini mengukur keefektifan dan efisiensi penggunaan rancang bangun virtual 3D desain Taman Tingkir. Evaluasi harus benar-benar terjadi di seluruh proses desain taman kota, dalam setiap tahap desain, antara tahapan desain, dan setelah implementasi desain.

\section{HASIL DAN PEMBAHASAN}

\subsection{Tahap Studi Pendahuluan dan Analisa (Analize)}

Tahapan observasi dilakukan guna menggali data dari objek penelitian, yaitu Taman Tingkir. Yang diamati dalam kegiatan ini adalah aktifitas pengunjung, fungsi fasilitas yang ada, kondisi fasilitas dan kondisi di dalam dan luar Taman Tingkir. Dari hasil pengamatan tentang aktifitas pengunjung dapat terlihat bahwa pengunjung Taman Tingkir menikmati beberapa fasilitas yang ada seperti playground, gazebo, pendopo dan bangku taman.

Berdasarkan hasil pengamatan, ada beberapa fasilitas yang terlihat mangkrak, antara lain kolam ikan, alat fitness dan sangkar burung. Kolam ikan pada Taman Tingkir dibangun dengan cukup besar, lokasinya di dalam taman tingkir adalah bagian depan. Kolam ini hanya berisi air dibagian pinggir.Sedangkan di tengah hanya ada rerumputan dan bangunan air mancur yang tidak menyala terletakdi tepat tengah kolam tersebut. Fasilitas selanjutnya yang terbengkalai adalah sangkar burung.Pada awal pembuatan sangkar ini berbagai macam burung, tetapi sekarang hanya tersisa sangkarnya saja, padahal sangkar burung ini berukuran cukup besar.

Selayaknya taman kota, Taman Tingkir juga mempunyai fasilitas yang sering kita jumpai di taman taman kota lainnya, yaitu playground.Playground adalah tempat yang dirancang khusus untuk memungkinkan anak-anak bermain di sana. Playground biasanya terletak di luar ruangan atau outdoor. Pada Taman Tingkir, playground merupakan fasilitas yang ramai dikunjungi oleh anak-anak. Tetapi kondisi tempat bermain di taman ini kurang membuat anak-anak nyaman dalam bermain, pasalnya alas tempat bermain yang berupa pasir dan kerikil. Bahan tersebut dapat tertiup angin dan becek pada saat hujan. Padatitik titik tertentu juga terlihat genangan air yang terlihat. Area bermain di Taman Tingkir tersedia dalam dua titik, yaitu di bagian depan taman sebelah timur dan barat. Fasilitas selanjutnya adalah pendopo dan gazebo. Fasilitas ini biasa digunakan pengunjung untuk berkumpul atau sekedar beristirahat sembari melihat pemandangan di area taman

Pada tengah tengah taman tingkir terdapat sebuah bangunan yang cukup besar dengan bentuk dasar lingkaran. Bangunan ini seolah olah menjadi pusat kegiatan di Taman Tingkir.Bangunan ini berisi beberapa bangku dan alat-alat fitness.

Fasilitas yang selalu kita jumpai pada setiap taman adalah bangku taman. Fasilitas ini berfungsi sebagai tempat untuk duduk-duduk sejenak untuk beristirahat sembari menikmati pemandangan dalam taman. Pada Taman Tingkir, banyak tersedia bangku taman. Bangku taman disini terdiri dari bahan besi, beton dan kaca. Berbentuk setengah tabung yang dibuat dari tong besi yang dipotong secara vertikal lalu diisi beton sebagai alas duduk. Lalu kaca sendiri adalah botol kaca, botol kaca ini berfungsi sebagai ornamen dalam kursi.Kursi ini ditopang dengan beton. Pembuatan kursi ini adalah bentuk dari bagian dari recycle barang-barang bekas.

Untuk tempat sampah, sebenarnya sudah banyak tersedia pada taman ini. Tempat sampah sudah dibuat dengan tiga bagian yang memisahkan berbagai jenis sampah. Tetapi beberapa tempat sampah tidak terisi dengan tong sampah, sehinga pengunjung harus mencari ke tempat yang lain. Dan tempat sampahpun hanya berisi satu tong sampah, dimana seharusnya berisi tiga tong sampah.

Beralih kebagian luar taman, taman ini dikelilingi oleh trotoar yang bisa berfungsi sebagai tempat pejalan kaki dan jogging track. Sebenarnya secara fisik trotoar di Taman Tigkir sudah masuk kedalam kategori aman dan nyaman. Namun pedagang yang menjajakan dagangan atau jasanya di area trotoar membuat area ini menjadi lebih sempit sehingga trotoar pada Taman Tingkir menjadi tidak lagi aman dan nyaman. Pejalan kaki juga harus berhati-hati saat berjalan di trotoar taman ini, dikarenakan persewaan mainan mobil yang berjalan di atas trotoar, bahkan sampai kedalam taman.

Pengunjung yang membawa kendaraan pribadi berupa motor akan memakirkan kendaraannya pada bahu jalan Taman Tingkir. Dikarenakan pada bahu jalan juga terdapat gerobak pedagang, maka terlihat tidak rapi pada parkir motor ini.Lalu pada parkir mobil, separuh lahan digunakan untuk wahana bermain anak. Pada saat akhir pekan, pengunjung Taman Tingkir begitu banyak, hal itu membuat parkir mobil

JURNAL ILMIAH KOMPUTER GRAFIS Vol. 13, No. 1, Juli 2020 : 1 - 8


terlihat penuh. Jika lahan parkir mobil sudah tidak ada, maka pengunjung yang datang menggunakan mobil akan mencari lokasi parkir di bahu jalan, atau bahkan tidak jadi berkunjung ke Taman Tingkir. Hal tersebut sangat disayangkan apabila pengunjung batal mengunjungi Taman Tingkir.

Wawancara dilakukan oleh peneliti kepada pengelola Taman Tingkir. Taman ini dikelola oleh Dinas Lingkungan Hidup Kota Salatiga bagian Pertamanan dan JPU. Kepala bidang Pertamanan dan JPU adalah Bapak Junirispinuddin, S.T.,M.T. Beliau bertugas sebagai kepala bidang Pertamanan dan JPU sejak Januari 2020. Dalam wawancara tidak terstruktur ini, penulis menanyakan kolam yang ada pada bagian depan Taman Tingkir. Dan beliau menjelaskan bahwa kolam tersebut adalah kolam retensi, kolam itu berfungsi sebagai penadah air hujan agar air tersebut tidak mengalir ke arah luar taman. Sebetulnya ada alternatif lain selain membangun kolam retensi, yaitu dengan cara membuat sumur resapan.

Pada penelitian ini, kuesioner dibagikan dua kali pada pengunjung Taman Tingkir.Kuesioner pertama dilakukan pada saat sebelum perancangan, sedangkan kuesioner kedua dibagikan setelah produk desain jadi dan telah divalidasi oleh dosen pakar dan user.Kuesioner dibagikan kepada 30 responden. Responden disini adalah para pengujnung Taman Tingkir yang berusia lebih dari 17 tahun baik laki-laki maupun perempuan. Kuesioner pertama berisikan pernyataan-pernyataan tentang kondisi Taman Tingkir berdasarkan dari hasil observasi pada objek penelitian yang dilakukan oleh peneliti, yaitu :

- Pernyataan fasilitas yang tersedia di Taman Tingkir sudah lengkap dari 30 responden menyatakan $80 \%$ Sangat Setuju dan 20\% Setuju.

- $\quad$ Pernyataan semua fasilitas tidak berfungsi sebagaimana mestinya dari 30 responden menyatakan $40 \%$ Sangat Setuju dan 60\% Setuju.

- Pernyataan ada titik-titik tertentu di dalam Taman Tingkir yang mengurangi keindahan taman dari 30 responden menyatakan 10\% Sangat Setuju dan 90\% Setuju.

- $\quad$ Pernyataan Arena bermain anak yang kurang nyaman dan aman dari 30 responden menyatakan 80\% Setuju dan 20\% Tidak Setuju.

- $\quad$ Pernyataan kurang nyamannya pejalan kaki dari 30 responden menyatakan $40 \%$ Sangat Setuju, 50\% Setuju dan $10 \%$ Tidak Setuju.

- $\quad$ Pernyataan pedangang di sekitar Taman Tingkir tidak tertata dengan rapi dari 30 responden menyatakan 30\% Sangat Setuju, 60\% Setuju dan 10\% Tidak Setuju.

- $\quad$ Pernyataan Area parkir pengunjung Taman Tingkir tidak tertata dengan rapi dari 30 responden menyatakan 10\% Sangat Setuju, 80\% Setuju dan 10\% Tidak Setuju.

- $\quad$ Pernyataan pohon pohon yang berada di dalam taman sudah membuat taman teduh dan sejuk dari 30 responden menyatakan 10\% Sangat Setuju, 70\% Setuju dan 20\% Tidak Setuju.

- $\quad$ Pernyataan Taman Tingkir sudah pantas digunakan untuk Ruang Publik dari 30 responden menyatakan $100 \%$ Sangat Setuju.

- $\quad$ Pernyataan perlu adanya ciri khas pada desain Taman Tingkir dari 30 responden menyatakan $40 \%$ Sangat Setuju dan 60\% Setuju.

\subsection{Tahap Perencanaan dan Perancangan Desain (Design \& Develop)}

Konsep redesain pada penelitian ini adalah Urban Landscape Design. Konsep urban sendiri mempunyai garis besar yaitu memanfaatkan sumber daya dan tata guna lahan sekitar yang ada pada masa kini dan membentuknya menjadi sebuah karya atau bangunan yang dapat menunjang aktifitas manusia dalam kehidupan sehari hari dan nantinya akan dicintai banyak orang karena pada dasarnya bentukan desain yang telah dihasilkan dapat meghadirkan suatu wilayah yang terpadu dengan pola perkembangan kota. Selain itu, kata urban sendiri sering dikaitkan dengan gedung-gedung perkotaan yang menjulang tinggi. Oleh karena itu, beberapa bangunan dibuat dengan bentuk menjulang atau tinggi. Denah Taman Tingkir bias dilihat dalam dibawah ini (gambar 4)

Hal pertama yang dibahas pada taman ini adalah landmark. Landmark sendiri bertujuan sebagai penanda atau ciri khas dari suatu wilayah.Taman Tingkir berlokasi di Kecamatan Tingkir Kota Salatiga.Sete lah melakukan observasi dari beberapa literatur, Kecamatan Tingkir adalah cikal bakal lahirnya kesenian Drumblek, tepatnya berada di kamoung Pancuran, Kelurahan Kutowingangun. Drumblek adalah sebuah kesenian yang hampir mirip dengan Marching Band,akan tetapi alat-alat yang digunakan kebanyakan berasal dari barang bekas seperti tong besi atau blek, drum plastik dan bambu. Jenis kesenian ini dicetuskan oleh Didik Subiantoro Masturi pada tahun 1986.Pada awal mula kemunculannya, kesenian ini hanya memakai pakaian sederhana dan juga sandal theklek. Ciri khas itulah yang membuat warga

\section{Virtual 3D Urban Landscape Design Taman Kota Berbasis Teknologi Komputer} Grafis 
Kampung Pancuran meraih penghargaan dari MURI ( Museum Rekor Dunia Indonesia ) untuk kategori pawai dengan menggunakan theklek dengan peserta terbanyak. Kampung Pancuran kemudian dikenal juga sebagai barisan theklek sebagai ciri khasnya.

Landmark pada Taman Tingkir dibuat dengan bentuk patung pemain drumblek (gambar 5). Patung ini diletakkan pada bagian depan Taman Tingkir, atau pada jalan masuk utama. Patung dibuat seperti monumen, yaitu patung ditopang dengan pilar, sehingga patung terlihat tinggi. Hal tersebut akan membuat patung tersebut menjadi menonjol dan mudah dilihat sehingga akan mendapat perhatian dari pengunjung.
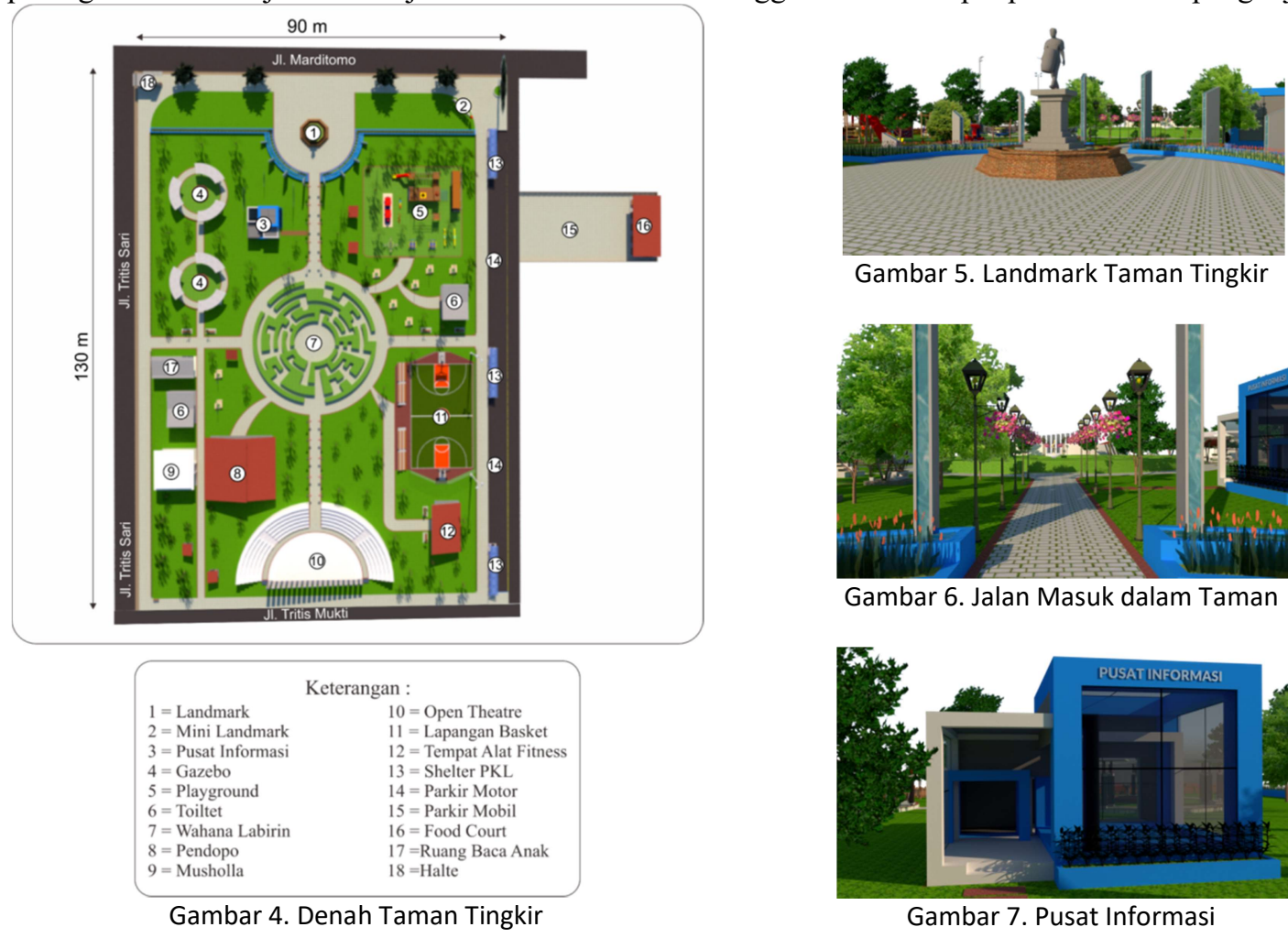

Gambar 6. Jalan Masuk dalam Taman

Pada sekitar landmark, akan terlihat bentuk bangunan yang menjulang dari rendah ke tinggi, hal ini merupakan gambaran dari gedung gedung perkotaan dari konsep Urban Design. Pada bagian tengah bangunan ini, akan ada air mengalir yang bertujuan mengisi kolam air kecil dibawahnya. Suara gemericik air akan membuat suasana hati pengunjung nyaman saat mengunjungi taman ini.

Berlanjut kejalan masuk taman (gambar 6), pengunjung akan disuguhkan jalan lurus dengan lampu dan pot yang menggantung. Bentuk tersebut bertujuan agar pengunjung mendapatkan spot selfie yang bagus dalam taman.

Pada sebelah jalan masuk, terdapat bangunan Pusat Informasi(gambar 7). Bangunan ini berfungsi sebagai pusat informasi pada taman ini sekaligus menjadi tempat untuk orang yeng mengelola taman ini. Diletakkan di dekat pintu utama agar orang dengan mudah untuk mendatanginya. Bangunan ini mempunyai ukuran $7,5 \mathrm{~m} \times 7,5 \mathrm{~m}$.

Di bagian belakang bangunan Pusat Informasi, terdapat gazebo (gambar 8) yang berbentuk lingkaran dengan diameter $13 \mathrm{~m}$.Kursi pada bangunan ini ditata melingkar dengan kursi menghadap ke tengah-tengah lingkaran. Fungsi dari gazebo ini bisa berbagai macam, contohnya adalah sebagai tempat beristirahat sembari menikmati suasana taman dan bisa juga untuk tempat berkumpul dalam skala kecil.
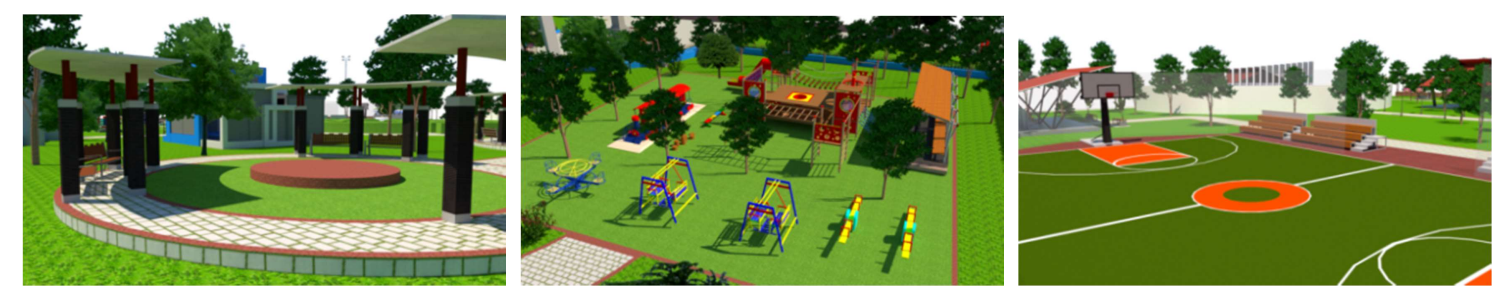

JURNAL ILMIAH KOMPUTER GRAFIS

Vol. 13, No. 1, Juli 2020 : $1-8$ 
Pada bagian Timur Taman Tingkir, bagian ini terdapat tempat permainan anak atau playground (gambar 9). Pada lokasi ini, alas yang digunakan adalah rumput sintetis seluas $24 \mathrm{~m} \times 21 \mathrm{~m}$, sehingga nantinya rumput tidak akan mudah rusak karena terinjak injak oleh pengunjung. Hal tersebut membuat minimnya masalah seperti genangan air dan debu seperti yang terjadi pada saat ini.

Pada sisi timur Taman Tingkir sebelah belakang, terdapat lapangan olahraga basket (gambar 10) dan juga tempat untuk fitness (gambar 11). Lapangan basket masih pada lokasi semula pada taman ini. Lapanganini berukuan keseluruhan 31,6m x 20m, dengan ukuran lapangan standart FIBA (International Basket Federation) yaitu 26m x 14m.Pada samping lapangan ini, ditambahkan tribun kecil untuk pengujung yang ingin melihat ke arah lapangan.Hal tersebut diharapkan dapat membuat lapangan basket terpakai lebih baik. Untuk tempat alat-alat fitness sendiri, bangunannya berukuran $10 \mathrm{~m} \times 5 \mathrm{~m}$.

Pada bagian tengah lapangan, peneliti menempatkan wahana labirin kecil (gambar 12) yang berdiameter 30m di tengah wahana. Ditengah wahana labirin tersebut terdapat air mancur mini. Wahana ini berfungsi sebagai tempat bermain anak bersama keluarga.Demi keamanan, wahana labirin ini hanya dibuat dengan tinggi 1 meter.Pada saat sampai tengah wahana labirin, pengunjung bisa duduk-duduk sembari menikmati suara gemercik air pada air mancur ini.

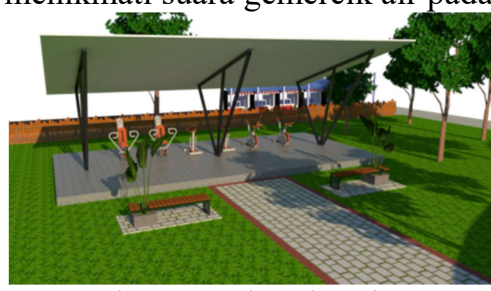

Gambar 11. Alat-alat Fitness

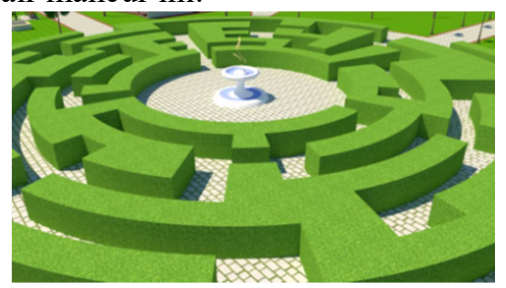

Gambar 12. Wahana Labirin

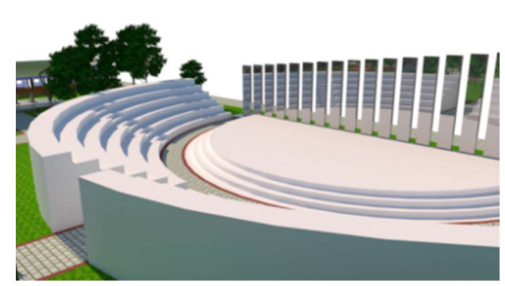

Gambar 13. Panggung Terbuka

Pada bagian belakang taman, akan terlihat bangunan yang cukup besar. Bangunan ini merupakan bangunan panggung terbuka atau open theatre (gambar 13). Bangunan ini berbentuk setengah lingkaran dengan ukuran $38 \mathrm{~m}$ x 20m. Open Thatre ini menjadi pembeda dari taman-taman kota lain di Kota Salatiga. Bangunan ini memiliki latar belakang berupa bentuk bangunan yang menjulang dari tinggi ke rendah.Bentuk tersebut diadaptasi dari bentuk dari alat musik bellyra. Alat musik tersebut adalah salah satu musik yang membentuk melodi pada kesenian drumblek.Nantinya panggung ini dapat menjadi panggung kesenian untuk warga Tingkir maupun warga Salatiga dan sekitarnya. Sehingga ada tujuan lain untuk mengunjungi taman ini.

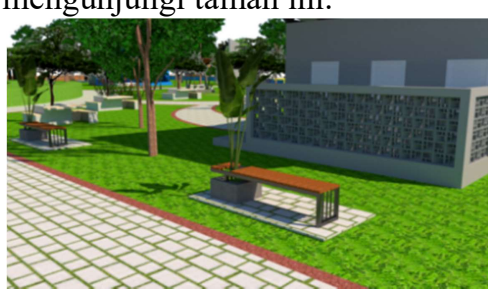

Gambar 14. Bangku Taman 1

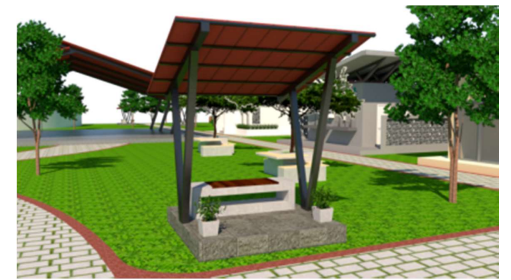

Gambar 15. Bangku Taman 2

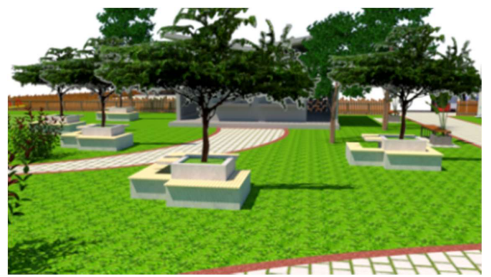

Gambar 16. Bangku Taman 3

Hal hal yang sering dijumpai pada taman antara lain seperti bangku taman dan tong sampah. Ada 3 tipe bangku taman yang didesain. Tipe pertama adalah bangku besi yang ditopang pada pot di salah satu sisinya dengan ukuran $150 \mathrm{~cm}$ x $50 \mathrm{~cm}$ (gambar 14). Tipe bangku kedua adalah bangku dengan bahan beton yang mempunyai atap dengan ukuran keseluruhan $150 \mathrm{~cm}$ x $150 \mathrm{~cm}$ (gambar 15). Lalu tipe bangku ketiga adalah bangku dengan meja disebagain sisi, bangku ini memiliki atap alami berupa pohon (gambar 16). Pohon yang digunakan adalah pohon Cersen atau dalam bahasa jawa biasa disebut talok. Bangku ini memiliki dimensi $200 \mathrm{~cm}$ x $200 \mathrm{~cm}$.

Pada bagian luar Taman Tingkir, desain yang sangat diperhatikan adalah penataan Pedagang Kaki Lima. Para pedagang ditata pada bagian timur taman, sehingga pedagang terpusat disebelah timur taman. Desain dibuat dengan menggunakan pondokan pondokan, atau biasa disebut sebahai shelter PKL (gambar 17). Shelter disini berjumlah sebanyak 24 pondok dengan ukuran masing masing pondok sebesar $2 \mathrm{~m} \times 2 \mathrm{~m}$.

\footnotetext{
Virtual 3D Urban Landscape Design Taman Kota Berbasis Teknologi Komputer Grafis
} 
Selanjutnya pada bagian parkir mobil, dibuatkan food court (gambar 18) sebanyak 5 buah dengan masingmasing berukuran $6 \mathrm{~m} \times 3 \mathrm{~m}$. Sehingga semua kegiatan perdagangan dapat terpusat disebelah timur taman. Pada desain pagar (gambar 20), gaya desain diambil dengan bentuk tinggi rendah seperti pada equalizer pada musik.

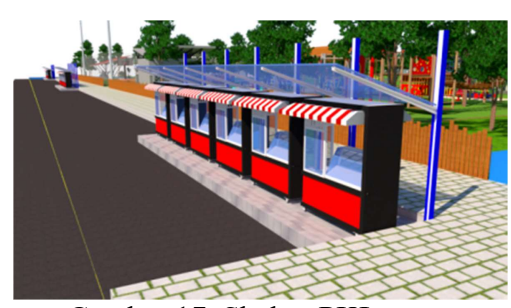

Gambar 17. Shelter PKL

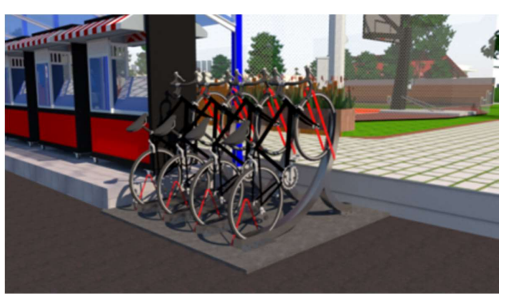

Gambar 19. Rak Sepeda

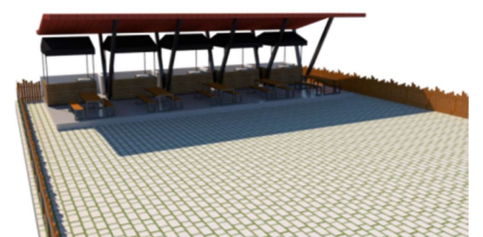

Gambar 18. Food Court pada Parkir Mobil

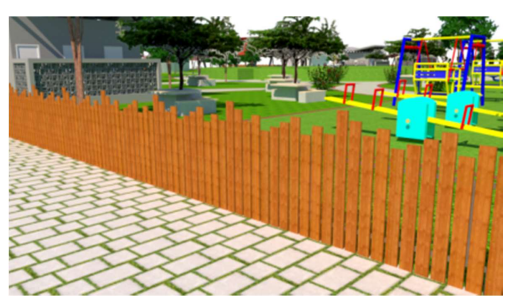

Gambar 20. Pagar Taman

\section{Produk Video}

Selain hasil render gambar, peneliti juga membuat produk berupa video. Video disini berisi tentang hasil desain dari beberapa sudut, dan pergerakan dari lokasi satu ke lokasi lainnya, sehingga dengan melihat video tersebut dapat dibayangkan seperti apa bentuk desainnya. Video ini berdurasi 7 menit 19 detik dengan resolusi $720 \mathrm{p}(1280 \times \mathrm{x} 20)$ dan frame rate $24 \mathrm{fps}$.

\subsection{Tahap Evaluasi}

Validasi ahli dilakukan dengan responden dari ahli dan pengguna. Validasi dilakukan untuk menguji kevalidan produk yang telah dibuat, sehingga diperoleh masukan untuk perbaikan produk. Kriteri pengujian (table 2) dan nilai validitasnya (table 3 ) dapat dilihat sebagaimana berikut :

Tabel 2. Kriteria Pengujian

\begin{tabular}{|l|l|}
\hline \multicolumn{1}{|c|}{ Kriteria Penilaian } & \multicolumn{1}{c|}{ Indikator } \\
\hline Urban Landscape Design & Bentuk bangunan sudah sesuai \\
\hline & Pewarnaan bangunan sudah sesuai \\
\hline Public Space & Pemanfaatan ruang \\
\hline & Kelengkapan fasilitas \\
\hline & Kegunaan fasilitas \\
\hline & Tata letak fasilitas \\
\hline Taman Kota & Akses dan pergerakan di lingkungan taman \\
\hline & Dapat diakses semua kalangan \\
\hline & Mengakomodasi kebutuhan rekreasi \\
\hline & Sebagai penghias kota \\
\hline & Fungsi sosial bagi warga kota \\
\hline
\end{tabular}

Tabel 3. Persentase Kelayakan

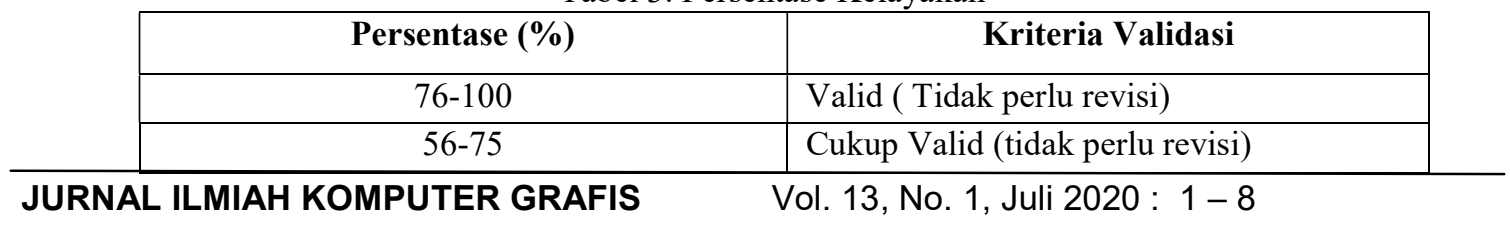




\begin{tabular}{|c|l|}
\hline $40-55$ & Kurang Valid (Revisi) \\
\hline $0-39$ & Tidak Valid (Revisi) \\
\hline
\end{tabular}

Rumus yang digunakan adalah :

Persentase $=\frac{\Sigma X}{\Sigma X \mathrm{i}} \times 100 \%$

Keterangan :

$\sum X$ : Jumlah nilai jawaban responden

$\sum \mathrm{X}_{\mathrm{i}}$ : Jumlah nilai ideal.

Selanjutnya adalah tahap evaluasi, dengan melakukan uji validasi oleh penguji ahli. Penguji ahli disini adalah Dosen Desain Grafis. Berikut merupakan hasil dari Uji Validasi Penguji ahli

Tabel 4. Hasil Uji Validasi Penguji ahli

\begin{tabular}{|c|c|c|c|c|c|c|}
\hline \multirow{2}{*}{ No } & \multirow{2}{*}{ Aspek yang diamati } & \multicolumn{5}{|c|}{ Nilai Pengamatan } \\
\hline & & 1 & 2 & 3 & 4 & 5 \\
\hline \multirow[t]{4}{*}{1} & Urban Landscape Design & & & & & \\
\hline & $\begin{array}{ll}\text { a. } & \text { Bentuk bangunan sudah sesuai }\end{array}$ & & & & $\sqrt{ }$ & \\
\hline & b. Pewarnaan bangunan sudah sesuai & & & & $\sqrt{ }$ & \\
\hline & c. Pemanfaatan ruang & & & & $\sqrt{ }$ & \\
\hline \multirow[t]{6}{*}{2} & Public Space & & & & & \\
\hline & $\begin{array}{ll}\text { a. } & \text { Kelengkapan fasilitas } \\
\end{array}$ & & & & $\sqrt{ }$ & \\
\hline & b. Kegunaan fasilitas & & & & $\sqrt{ }$ & \\
\hline & c. Tata letak fasilitas & & & & $\sqrt{ }$ & \\
\hline & d. Akses dan pergerakan di lingkungan taman & & & & $\sqrt{ }$ & \\
\hline & e. Dapat diakses semua kalangan & & & & $\sqrt{ }$ & \\
\hline \multirow[t]{8}{*}{3} & Taman Kota & & & & & \\
\hline & $\begin{array}{ll}\text { a. } & \text { Mengakomodasi kebutuhan rekreasi }\end{array}$ & & & & & $\sqrt{ }$ \\
\hline & b. Sebagai penghias kota & & & & $\sqrt{ }$ & \\
\hline & c. Fungsi sosial bagi warga kota & & & & $\sqrt{ }$ & \\
\hline & Jumlah Skor & & & & 40 & 5 \\
\hline & Total Skor & \multicolumn{5}{|c|}{45} \\
\hline & Skor Ideal & \multicolumn{5}{|c|}{55} \\
\hline & Persentase Kelayakan & \multicolumn{5}{|c|}{$81,8 \%$} \\
\hline
\end{tabular}

Dari hasil uji validasi oleh Penguji ahli di atas, dapat diketahui total skor dari uji validasi. Dari total skor tersebut, dapat ditemukan nilai persentase sebesar $81,8 \%$. Angka persentase tersebut sudah Valid ( tidak perlu revisi ) seperti apa yang tertera pada tabel 4 .

Dikarenakan hasil dari uji validasi pertama adalah valid, maka dilakukan pengujian tahap kedua yang dilakukan oleh Penguji Pengguna. Penguji pengguna disini adalah pihak Bidang Pertamanan Dinas Lingkungan Hidup Kota Salatiga. Berikut merupakan hasil dari Uji Validasi Penguji pengguna.

Tabel 5. Hasil Uji Validasi Penguji Pengguna

\begin{tabular}{|c|c|c|c|c|c|c|c|}
\hline \multirow{2}{*}{ No } & Aspek yang diamati & \multicolumn{5}{|c|}{ Nilai Pengamatan } \\
\hline & & 1 & 2 & 3 & 4 & 5 \\
\hline 1 & Urban Landscape Design & & & & & \\
\hline & d. Bentuk bangunan sudah sesuai & & & & $\sqrt{ }$ & \\
\hline & e. Pewarnaan bangunan sudah sesuai & & & $\sqrt{ }$ & & \\
\hline & f. Pemanfaatan ruang & & & & $\sqrt{ }$ & \\
\hline 2 & Public Space & & & & & \\
\hline & f. Kelengkapan fasilitas & & & & $\sqrt{ }$ & \\
\hline & g. Kegunaan fasilitas & & & & $\sqrt{ }$ & \\
\hline
\end{tabular}

Virtual 3D Urban Landscape Design Taman Kota Berbasis Teknologi Komputer Grafis 


\begin{tabular}{|c|c|c|c|c|c|}
\hline & h. Tata letak fasilitas & & & $\sqrt{ }$ & \\
\hline & i. Akses dan pergerakan di lingkungan taman & & & $\sqrt{ }$ & \\
\hline & j. Dapat diakses semua kalangan & & & & \\
\hline 3 & Taman Kota & & & & \\
\hline & d. Mengakomodasi kebutuhan rekreasi & & & $\sqrt{ }$ & \\
\hline & e. Sebagai penghias kota & & & $\sqrt{ }$ & \\
\hline & f. Fungsi sosial bagi warga kota & & & $\sqrt{ }$ & \\
\hline & Jumlah Skor & & 6 & 36 & \\
\hline & Total Skor & & 42 \\
\hline & Skor Ideal & \multicolumn{3}{|c|}{55} \\
\hline
\end{tabular}

Dari hasil uji validasi oleh Penguji Pengguna di atas, dapat diketahui total skor dari uji validasi. Dari total skor tersebut, dapat ditemukan nilai persentase sebesar 76,4\%. Angka persentase tersebut sudah Valid ( tidak perlu revisi ) seperti apa yang tertera pada tabel 5. Dalam angket ini, penguji pengguna memberikan saran berupa penambahan railing guard untuk difabel, halte dan kolam retensi / sumur resapan air.

Setelah produk selesai dirancang, peneliti menyebarkan kuesioner kedua atau kuesioner setelah perancangan kepada para responden. Responden disini adalah pengunjung Taman Tingkir yang berjumlah 30 orang. Penyebaran kuesioner ini bertujuan untuk mengetahui apakah desain yang dibuat layak untuk para pengunjung atau tidak. Kuesioner ini berisikan pernyatan terhadap hasil redesign yang telah dibuat oleh peneliti. Sebelum mengisi kuesioner, responden diperlihatkan produk desain yang berupa gambar hasil render dari aplikasi SketchUp yang digabungkan menjadi satu dalam sebuah booklet. Berikut merupakan hasil dari kuesioner kedua :

- $\quad$ Pernyataan Landmark yang telah dibuat dapat menjadi ciri khas dari Taman Tingkir dari 30 responden menyatakan 30\% Sangat Setuju dan 70\% Setuju.

- $\quad$ Pernyataan Fasilitas yang telah dibuat sudah cukup untuk Taman Tingkirdari 30 responden menyatakan 26,7\% Sangat Setuju dan 73,3\% Setuju.

- Pernyataan Fasilitas yang telah dibuat dapat menjangkau semua kalangandari 30 responden menyatakan 46,7\% Sangat Setuju dan 53,3\% Setuju.

- $\quad$ Pernyataan Arena bermain anak atau playground yang lebih baikdari 30 responden menyatakan 56,7\% Setuju dan $43,3 \%$ Tidak Setuju.

- $\quad$ Pernyataan Akses sirkulasi pedestrian ( pejalan kaki ) yang mencukupi 33,3\% Sangat Setuju dan66,7\% Setuju.

- $\quad$ Pernyataan Pembuatan shelter PKL membuat pedagang lebih tertata dengan rapi dari 30 responden menyatakan 33,3\% Sangat Setuju, 53,3\% Setuju dan 13,4\% Tidak Setuju.

- Pernyataan Pembuatan shelter PKL membuat trotoar Taman Tingkir manjadi aman dan nyamandari 30 responden menyatakan $40 \%$ Sangat Setuju dan60\% Setuju.

- $\quad$ Pernyataan Lokasi parkir yang terpusat membuat parkir lebih tertata dengan rapidari 30 responden menyatakan 37,7\% Sangat Setuju, 60\% Setuju dan 33,3\% Tidak Setuju.

- $\quad$ Pernyataan Halte memudahkan pengunjung yang menggunakan transportasi umum dari 30 responden menyatakan 83,3\% Sangat Setuju dan 16,7\% Setuju.

- Pernyataan Fasilitas yang telah dibuat menjadikan Taman Tingkir sebagai Public Space yang lebih baikdari 30 responden menyatakan 90\% Sangat Setuju dan 10\% Setuju.

\section{KESIMPULAN DAN SARAN}

Berdasarkan hasil penelitian pengembangan redesain taman Tingkir menggunakan Teknologi Komputer grafis ini dapat disimpulkan sebagai berikut :

Redesign Taman Tingkir dengan Konsep Urban Landscape Desain sebagai Public Space dengan pemanfaatan teknologi komuter grafis mampu memberikan gambaran nyata secara maya (virtual). Hasil pengembangan redesain Taman Tingkir masuk kategori Valid dengan skor rata rata yang diberikan oleh Penguji ahli yaitu 81,8\%. Dan skor rata rata yang diberikan oleh Penguji Pengguna adalah 76,4\%, skor tersebut masuk dalam kategori valid. Sehingga hasil redesain Taman Tingkir dapat digunakan sebagai pedoman atau acuan dalam pembuatan desain Taman Kota dengan Konsep Urban Landscape Design. Respon pengunjung yang diambil dari keusioner yang disebarkan setelah melihat produk desain yang telah divalidasi adalah pengunjung merasa puas dengan hasil redesain Taman Tingkir. Hal itu ditunjukkan JURNAL ILMIAH KOMPUTER GRAFIS Vol. 13, No. 1, Juli $2020: 1$ - 8 
dengan lebih dari $90 \%$ dalam setiap pernyataan yang diajukan, responden memilih pada pilihan bagian Setuju dan Sangat Setuju.

Pembahasan tentang redasain taman kota membutuhkan sudut pandang yang menyeluruh, sehingga semakin banyaknya tema atau konsep dari berbagai kategori yang berbeda. Pengungkapan fakta-fakta lainnya yang berhubungan dengan desain taman kota dapat dijadikan sebagai tambahan wawasan yang selama ini belum terungkap. Redesign Taman Tingkir dengan Konsep Urban Landscape Desain sebagai Public Space dengan pemanfaatan teknologi komuter grafis masih membahas hal-hal yang bersifat umum, perlu pendalaman yang lebih detail lagi mengenai penelitian ini. Diharapkan dengan adanya penelitian ini, dapat memicu munculnya penelitian penelitian sejenis yang mengangkat sudut pandang berbeda tentang taman kota. Tentunya bagi para pelaku yag terjun dalam dunia desain taman kota semakin memacu untuk lebih banyak berkontribusi dan memberikan informasi tentang desain taman kota melalui berbagai media yang beragam.

\section{DAFTAR PUSTAKA}

[1] Widayanti, F. T., \& Hadi, T. S. (2019). "Kajian Bentuk Karakter Ruang Taman Tingkir Sebagai Ruang Terbuka Hijau Perkotaan Kota Salatiga."Jurnal Planologi, 14(2), 117. https://doi.org/10.30659/jpsa.v14i2.3869

[2] Kustianingrum, D., Sukarya, A. K., Nugraha, R. A., \& Tyagarga, F. R. (2013). "Fungsi dan Aktifitas Taman Ganesha Sebagai Ruang Publik di Kota Bandung. "Jurnal Reka Karsa, 1(2),1-14.

[3] Permana, I. A., \&Fatimah, I. S. (2017). "Redesign Taman Kota Kabupaten Bogor Dengan Pendekatan Urban Landscape Design.", Jurnal Arsitektur Lansekap, 39. https://doi.org/10.24843/jal.2017.v03.i01.p05

[4] Nugroho, Y. A. (2018). "Keamanan dan Kenyamanan Trotoar di Taman Tingkir Kota Salatiga." Mintakat Jurnal Arsitektur, 18(1), 35-48.

[5] Syahputra, F. A., \& Arsitektur, J. (2018). "Penerapan Tema Urban Landscape pada Rancangan Terminal Leuwi Panjang ", Dwisasana Embara Parahyangan. III(1), 1-11.

[6] Ghassani, R., \& Arsitektur, J. (2019). "Pendekatan Konsep Urban Desain pada Rancangan Apartemen Living City Pasteur di Kota Bandung."IV(3), 1-11.

[7] Kustianingrum, D., Sukarya, A. K., Nugraha, R. A., \& Tyagarga, F. R. (2013). "Fungsi dan Aktifitas Taman Ganesha Sebagai Ruang Publik di Kota Bandung. "Jurnal Reka Karsa, 1(2),1-14.

[8] Nasution, A. D., \& Zahrah, W. (2017). "Public Open Space's Contribution to Quality of Life: Does privatisation matters?"Asian Journal of Environment-Behaviour Studies, 2(5), 71. https://doi.org/10.21834/aje-bs.v2i5.224

[9] Radnawati, D., Febriani, Y., \& Nurhayati, E. (2018). "Konsep bentuk kujang sebagai salah satu identitas eksistensi budaya Sunda dalam perencanaan taman di Kota Bogor."Jurnal Arsitektur Lansekap, 4(1), 90.

[10] Susilohadi, A. D., Soemardiono, B., \& Kharismawan, R. (2014). "Konsep Perancangan Menara Surabaya sebagai Landmark dalam Fenomena 'Iconisation.'"Jurnal Sains Dan Seni Pomits, 3(2), 19-21.

[11] Krisdianto, R. (2018). "Penerapan Media 3D Sketchup Pada Model Pembelajaran Langsung Mata Pelajaran Menggambar Dengan Perangkat Lunak Di SMK Negeri 1 Bendo Magetan."Jurnal Kajian Pendidikan Teknik Bangunan, 2(2/JKPTB/18).

[12] Maulana, H., \& Zarassita, D. (2017). "Pembuatan Brand Mark dan Motion Graphic Logo Pada Rebranding Project PT Astra Graphia Information Technology."Multinetics, 3(2), 18.

[13] Firmantoro, K., Anton, A., \& Nainggolan, E. R. (2016). "Animasi Interaktif Pengenalan Hewan Untuk Pendidikan Anak Usia Dini. "None, 13(2), 14-22.

[14] Muruganantham, G. (2015). Developing of E-content package by using ADDIE model. International Journal of Applied Research, 1(3), 52-54.

\section{Virtual 3D Urban Landscape Design Taman Kota Berbasis Teknologi Komputer} Grafis 